\title{
Impact of Nitrogen Fertilizer on Yield and Associated Revenues in No-tillage Pumpkin
}

\section{S. Alan Walters \\ Department of Plant, Soil, and Agricultural Systems, 1205 Lincoln Drive, Room 176 Agricultural Building, Southern Illinois University, Carbondale, IL 62901, MC 4415}

Additional index words. conservation tillage, Cucurbita pepo, fertilizer, gross/net revenues, reduced tillage, vegetable production

\begin{abstract}
The use of no tillage (NT) integrated with cover cropping is a management practice that is becoming more popular with commercial 'jack-o-lantern' pumpkin (Cucurbita pepo) growers in the eastern and midwestern United States, although little is known about nitrogen $(N)$ fertilizer requirements for this production system. A field study was established at the Southern Illinois University Horticulture Research Center in Carbondale to evaluate the yield response of pumpkin and associated revenues to $\mathrm{N}$ fertilization in a NT production system after wheat (Triticum aestivum) harvest. Nitrogen application rate affected pumpkin leaf chlorophyll content, and resulting yields and revenues. At all sampling dates, pumpkin fertilized with $224 \mathrm{~kg} \cdot \mathrm{ha}^{-1} \mathrm{~N}$ had the greatest leaf chlorophyll content. Quadratic relationships best described pumpkin fruit size and diameter increase with $\mathrm{N}$ rates from 0 to $224 \mathrm{~kg} \cdot \mathrm{ha}^{-1}$. Furthermore, pumpkin fruit number and weight per hectare also increased in a quadratic manner, as $\mathbf{N}$ application rates increased from 0 to $224 \mathrm{~kg} \cdot \mathrm{ha}^{-1}$. The application of $168 \mathrm{~kg} \cdot \mathrm{ha}^{-1} \mathrm{~N}$ also provided high yields and large fruit sizes, although quadratic models indicated that maximum net revenues for NT pumpkins were achieved with $224 \mathrm{~kg} \cdot \mathrm{ha}^{-1} \mathrm{~N}$. Growers applying 224 $\mathrm{kg} \cdot \mathrm{ha}^{-1} \mathrm{~N}$ would increase net revenues by $\approx 54 \%, 52 \%$, and $51 \%$ at pumpkin fruit price points of \$0.33, \$0.44, \$0.55 per $\mathrm{kg}$, respectively, compared with $0 \mathrm{~kg} \cdot \mathrm{ha}^{-1} \mathrm{~N}$ fertilization. An additional $123 \mathrm{~kg} \cdot \mathrm{ha}^{-1} \mathrm{~N}$ from fertilizer was required for NT pumpkin production after wheat harvest in fields with high amounts of cereal straw residues on the soil surface compared with the $101 \mathrm{~kg} \cdot \mathrm{ha}^{-1} \mathrm{~N}$ recommended for conventional tillage systems with no cover crop residues. This study suggests that $N$ fertilizer investments will provide significant monetary returns in NT pumpkin systems. However, the $168 \mathrm{~kg} \cdot \mathrm{ha}^{-1} \mathrm{~N}$ rate provided the highest return on fertilizer investment at all pumpkin pricing points compared with all other $\mathrm{N}$ rates evaluated. Additionally, pumpkins grown in NT systems using a winter grain crop that is ended at flowering should require similar $\mathrm{N}$ amounts, because little $\mathrm{N}$ is used during heading and grain ripening. Although growers often look for ways to reduce input costs in vegetable production systems, $\mathbf{N}$ fertilization is clearly an important investment that provides increased yields and revenues in NT pumpkins. The results of this study should provide additional information to establish $\mathbf{N}$ fertilizer recommendations for NT pumpkin production.
\end{abstract}

The use of NT practices for pumpkin (Cucurbita pepo) production is becoming popular in the eastern and midwestern United States (Harrelson et al., 2007; Morse et al., 2001; O'Rourke and Peterson, 2016; Rapp et al., 2004; Walters, 2016; Walters et al., 2008). Many growers understand that NT practices not only provide an effective, cost-efficient means of reducing soil erosion but will also increase soil organic matter and improve both water conservation and nutrient-holding capacities of soils (Johnson

Received for publication 4 Sept. 2019. Accepted for publication 16 Jan. 2020.

Published online 5 March 2020.

S.A.W. is the corresponding author. E-mail: awalters@ siu.edu.

This is an open access article distributed under the CC BY-NC-ND license (https://creativecommons. org/licenses/by-nc-nd/4.0/).

2016; Walters, 2016). Additionally, pumpkin fruit produced in NT systems tend to be cleaner with little to no soil attached onto the fruit skin surface, which results from pumpkins residing on cover crop or other crop residues. These pumpkins often garner a premium price compared with those fruit grown in conventional tillage (CT), which often have soil attached to the skin (Walters et al., 2008).

Fertility management in NT pumpkin production systems is essential to maximize fruit yield. Hoyt et al. (1994) indicated that nitrogen $(\mathrm{N})$ fertilizer rates must be adjusted for vegetables growing in NT compared with those recommended for CT. Moreover, Sanders (2006) indicated that an additional 22 to $34 \mathrm{~kg} \cdot \mathrm{ha}^{-1} \mathrm{~N}$ will need to be applied when small grain cover residues remain on the soil surface in NT vegetable systems. If additional $\mathrm{N}$ is not applied, cover crop mulch residues with high $\mathrm{C}: \mathrm{N}$ ratios residing on the soil surface may reduce the yield of the next vegetable crop grown due to $\mathrm{N}$ immobilization. Although winter grass cover crops, such as wheat (Triticum aestivum) or winter rye (Secale cereale), are often used in vegetable NT production systems to reduce soil erosion and to increase soil organic matter, these crops can temporarily tie up soil $\mathrm{N}$ in the spring and can have a slow rate of decomposition during the summer (Morse and Seward, 1986). Thus, these cover crops may create an $\mathrm{N}$ deficiency for the succeeding vegetable crop through microbial $\mathrm{N}$ assimilation, which creates $\mathrm{N}$ immobilization (Skarphol et al., 1987; Vyn et al., 1999). The decomposition of cover crop residues and subsequent $\mathrm{N}$ release is regulated in part by their $\mathrm{C}: \mathrm{N}$ ratio (Walters, 2016). Cover crop residues with a $\mathrm{C}: \mathrm{N}$ ratio greater than 25:1 may reduce the yield of the following vegetable crop due to net $\mathrm{N}$ immobilization (Francis et al., 1998; Paul and Clark, 1996; Schonbeck et al., 1993). However, uptake of $\mathrm{N}$ by grass cover crops can prevent some $\mathrm{N}$ losses due to leaching during the winter months and early spring and provide a slow release of $\mathrm{N}$ as residues decompose during the warmer months of the growing season (Knavel and Herron, 1986).

It is widely known that vegetables grown in NT systems with grass cover crop or cereal grain crop mulch residues on the soil surface require increased amounts of $\mathrm{N}$ fertilization compared with those grown in CT systems. However, the amount of $\mathrm{N}$ required is directly related to several factors, including soil type, crop grown, cover crop residues present, previous crops/cropping systems, and fertility management used in prior years. There is little available information regarding fertilizer recommendations for vegetable crops grown in NT production systems (Walters, 2016). Thus, the objective of this study was to determine the optimal $\mathrm{N}$ fertilization rate for NT pumpkin grown in fields with substantial amounts of cereal crop residue left on the soil surface following grain harvest.

\section{Materials and Methods}

A field study was conducted from 2009 to 2010 and 2010 to 2011 in different fields at the Southern Illinois University Horticultural Research Center in Carbondale to evaluate the effect of $\mathrm{N}$ fertilizer applications on NT pumpkin production. The soil type in both fields was a Hosmer silt loam (fine-silty, mixed, mesic Typic Fragiudalfs; Herman, 1979). During mid-Oct. 2009 and 2010, 'Pioneer 25R78' winter wheat was drill planted at 3.7 million seeds/ha. Fertilizer was applied before wheat was planted each year with 40 $\mathrm{kg} \mathrm{N}, 45 \mathrm{~kg}$ phosphorus (P), and $139 \mathrm{~kg}$ potassium $(\mathrm{K}) / \mathrm{ha}$ from diammonium phosphate $(18 \mathrm{~N}-20 \mathrm{P}-0 \mathrm{~K})$ and potassium chloride $(0 \mathrm{~N}-0 \mathrm{P}-31 \mathrm{~K})$. In early spring, an additional $100 \mathrm{~kg} \cdot \mathrm{ha}^{-1} \mathrm{~N}$ from urea ammonium nitrate solution $(28 \mathrm{~N}-0 \mathrm{P}-0 \mathrm{~K})$ was applied. Wheat was harvested mid-June each year, and 
within a week after harvest, four soil samples (at 10- to $15-\mathrm{cm}$ depths) were randomly collected from the field for analysis by Brookside Laboratories Inc. (New Knoxville, $\mathrm{OH})$. Soil analysis results were similar over the 2 years with $\mathrm{pH}$ of $7.0,1.8 \%$ organic matter content, and organic $\mathrm{N}$ (Kjeldahl method; Kjeldahl, 1883) at $62 \mathrm{~kg} \cdot \mathrm{ha}^{-1}$. For both years, the amount of $\mathrm{P}$ (by Bray I method; Bray and Kurtz, 1945) and K (by Mehlich III method; Mehlich, 1984) in the soil was 175 and $215 \mathrm{~kg} \cdot \mathrm{ha}^{-1}$, respectively; calcium content (by Mehlich III method; Mehlich, 1984) was $3800 \mathrm{~kg} \cdot \mathrm{ha}^{-1}$, equivalent to $82 \% \mathrm{Ca}^{2+}$ saturation of total cation exchange capacity.

The experiment was set up as a split-plot design with four replications. The main plots were three pumpkin cultivars Appalachian (Seedway, Elizabethtown, PA), Gold Medal (Rupp Seeds Inc., Wauseon, $\mathrm{OH}$ ), and Magic Wand (Harris Moran Seed, Modesto, CA). The subplots consisted of five $\mathrm{N}$ rates $\left(\mathrm{kg} \cdot \mathrm{ha}^{-1}\right): 0,56,112,168$, and 224, with the $\mathrm{N}$ application consisting of a $1: 1$ mixture (by weight) of calcium nitrate $(15.5 \mathrm{~N}-0 \mathrm{P}-0 \mathrm{~K})$ and a standard complete fertilizer $(13 \mathrm{~N}-6 \mathrm{P}-$ $7 \mathrm{~K}$ ), with half the application made on 10 July (broadcast) and the other half on 10 Aug. (sidedress) during each growing season. Both applications were made by hand using weight of fertilizers. Because the soil samples indicated that phosphorus and potassium levels were in sufficient ranges for pumpkin production (Egel et al., 2017), these nutrients should not have influenced results; further, no deficiency symptoms of these nutrients were observed on plants.

Pumpkin seeds were germinated in a greenhouse and grown in 72-cell plastic containers filled with a soilless media (2:1:1 peat:perlite:vermiculite ratio). Plants were hardened off in a coldframe 3 to $4 \mathrm{~d}$ before transplanting in the field. During late June each year, plants were transplanted into the field at the two- to three-leaf stage. Pumpkin transplants were planted into $13.2 \mathrm{~m}$-long subplots that had a 2-m alley between mainplots and center-to-center row spacings of $2.3 \mathrm{~m}$. Border plantings of 'Magic Wand' was included on each side of the main plot, with each mainplot $13.2 \mathrm{~m}$ long and $11.5 \mathrm{~m}$ wide. Because each pumpkin cultivar evaluated produces a different mature vine size, inrow spacings were $1.3,1.6$, or $2 \mathrm{~m}$ for 'Magic Wand', 'Appalachian', and 'Gold Medal', respectively; this allowed 10,8 , and 6 plants to be grown in each plot for 'Magic Wand', 'Appalachian', and 'Gold Medal', respectively. 'Magic Wand' produces mediumsized vines that bear 7 - to $11-\mathrm{kg}$ dark orange fruit with a flattened, round shape and large firm handle. 'Appalachian' produces a semibush type plant that produces 8 - to $11-\mathrm{kg}$, slightly elongated, smooth-ribbed, dark orange fruit with strong handles. 'Gold Medal' has very large vines, and $14-$ to $18-\mathrm{kg}$ fruit with deep orange color, moderate ribbing, fairly uniform round shape, and thick, strongly attached stems.

Pumpkins were transplanted after wheat harvest, and therefore a burndown herbicide
(1.6 L.ha ${ }^{-1}$ glyphosate; Roundup WeatherMax, Monsanto, St. Louis, MO) was applied to the entire field $7 \mathrm{~d}$ before pumpkin seedling transplanting, and s-metolachlor (Dual Magnum; Syngenta Crop Protection, Greensboro, $\mathrm{NC})$ at $1.55 \mathrm{~L} \cdot \mathrm{ha}^{-1}$ was applied $3 \mathrm{~d}$ before transplanting. Spot applications of paraquat (Gramoxone Inteon; Syngenta Crop Protection) at $3.5 \mathrm{~L} \cdot \mathrm{ha}^{-1}+1 \% \mathrm{v} / \mathrm{v}$ crop oil concentrate (COC; Growmark, Bloomington, IL) were made to noncrop areas before pumpkin vines had spread across the soil surface. All herbicide treatments were applied with a $\mathrm{CO}_{2}$-pressurized backpack sprayer using XR 8003 flat-fan spray tips (TeeJet; Spraying Systems, Wheaton, IL) at $40 \mathrm{psi}$ in $187 \mathrm{~L} \cdot \mathrm{ha}^{-1}$ water. Overhead irrigation was used to incorporate the preemergence herbicide into the soil $(1.25 \mathrm{~cm}$ water was applied within a day after herbicide application) and provide at least $2.5 \mathrm{~cm}$ of water per week throughout the growing season, which include rainfall events.

Table 1. Influence of pumpkin cultivar and nitrogen fertility rate on leaf chlorophyll content, pumpkin yield, and fruit parameters.

\begin{tabular}{|c|c|c|c|c|c|c|}
\hline \multirow[b]{2}{*}{ Pumpkin cultivar } & \multicolumn{2}{|c|}{ Leaf chlorophyll content ${ }^{z}$} & \multicolumn{2}{|c|}{ Pumpkin yield $(\times 1000)^{\mathrm{y}}$} & \multicolumn{2}{|c|}{ Pumpkin fruit $^{\mathrm{x}}$} \\
\hline & Midseason & Late season & no./ha fresh & $\mathrm{Wt}(\mathrm{kg}) / \mathrm{ha}$ & Size $(\mathrm{kg})$ & Diam $(\mathrm{cm})$ \\
\hline Appalachian & $40.8 \mathrm{a}^{\mathrm{w}}$ & $37.1 \mathrm{a}$ & $6.9 \mathrm{a}$ & $48.8 \mathrm{a}$ & $7.1 \mathrm{~b}$ & $23.2 \mathrm{c}$ \\
\hline Gold Medal & $40.1 \mathrm{a}$ & $35.8 \mathrm{a}$ & $5.4 \mathrm{~b}$ & $43.7 \mathrm{ab}$ & $8.1 \mathrm{a}$ & $28.2 \mathrm{a}$ \\
\hline Magic Wand & $41.3 \mathrm{a}$ & $35.4 \mathrm{a}$ & $6.9 \mathrm{a}$ & $39.0 \mathrm{~b}$ & $5.7 \mathrm{c}$ & $25.7 \mathrm{~b}$ \\
\hline
\end{tabular}

${ }^{\mathrm{z}}$ Leaf chlorophyll content was determined using a Konica Minolta SPAD-502 chlorophyll meter (Special Products Analysis Division, Konica Minolta Sensing, Inc., Osaka, Japan) on five mature leaves near the center of three randomly selected plants in each plot. Mid- and late season sampling dates each year were 10 Aug. and 10 Sept., respectively.

${ }^{\mathrm{y}}$ The number and weight of mature, orange-colored pumpkins were determined in each experimental unit at two harvests on 10 Sept. and 10 Oct. of each year.

${ }^{\mathrm{x}}$ Pumpkin fruit size was calculated based on yields, dividing wt./ha by no./ha. Fruit diameter was collected from mature, orange-colored pumpkins in each experimental unit at two harvests on 10 Sept. and 10 Oct. each year.

${ }^{\text {w} M e a n s ~ s e p a r a t e d ~ b y ~ t h e ~ s a m e ~ l e t t e r ~ w i t h i n ~ a ~ c o l u m n ~ a r e ~ n o t ~ s i g n i f i c a n t l y ~ d i f f e r e n t ~ a c c o r d i n g ~ t o ~ F i s h e r ' s ~}$ protected least significant difference at $P \leq 0.05$.

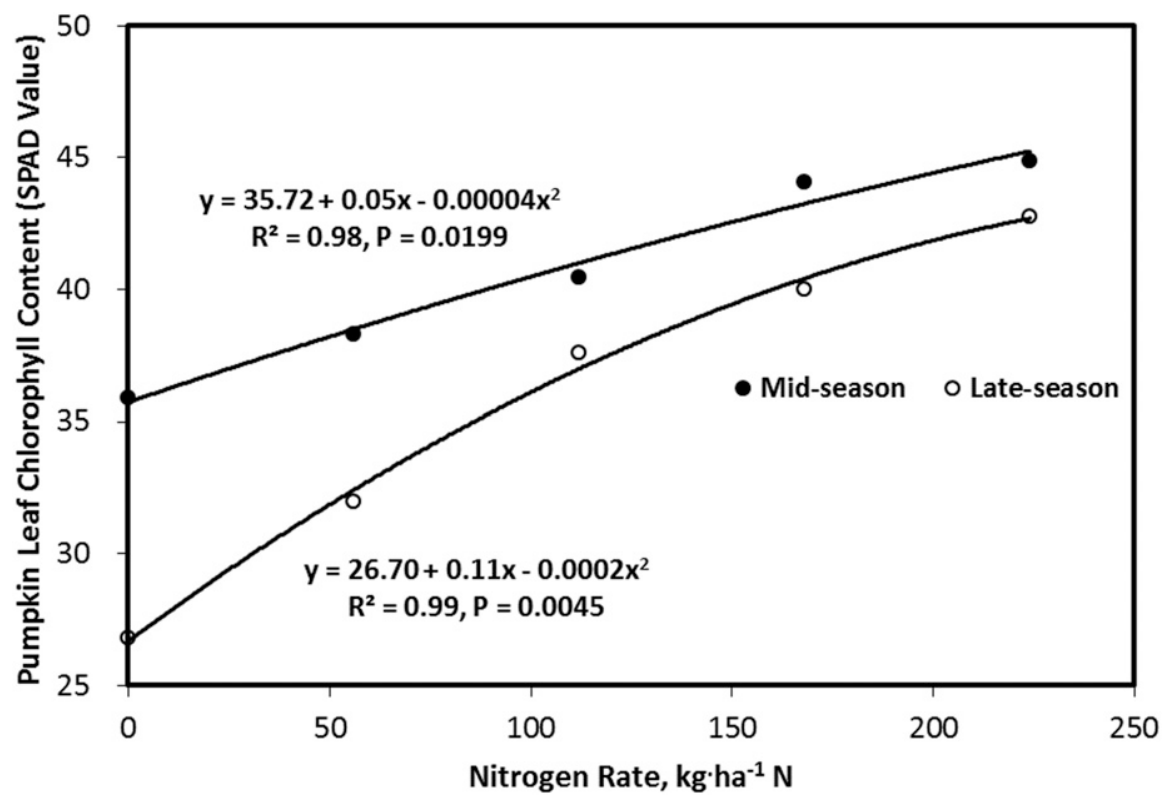

Fig. 1. Response of pumpkin leaf chlorophyll content to nitrogen $(\mathrm{N})$ fertilizer rate at mid- and late season in a no-tillage production system. Mid and late season sampling dates were 10 Aug. and 10 Sept., respectively. 
using a Konica Minolta SPAD-502 chlorophyll meter (Special Products Analysis Division, Konica Minolta Sensing, Inc., Osaka, Japan) on five mature leaves near the vine center of four randomly selected plants in each plot. The number, fresh weight $(\mathrm{kg})$, and diameter $(\mathrm{cm})$ of mature, orange-colored pumpkins were determined for each experimental unit at two harvests on 10 Sept. and 10 Oct. each year.

A partial budget analysis was used to determine the effect of fertilizer costs on NT pumpkin yields and revenues at different $\mathrm{N}$ rates. The $\mathrm{N}$ applied was a 1:1 mixture of calcium nitrate + standard complete fertilizer, with $\mathrm{N}$ fertilizer costs of $\$ 4.74$ and $\$ 4.39$ per $\mathrm{kg}$ for these fertilizers, respectively (Southern FS Corp., Cobden, IL). When the fertilizers were mixed and application fees at $\$ 0.22 / \mathrm{kg} \mathrm{N}$ were added, this equated to $\$ 4.79$ / $\mathrm{kg} \mathrm{N}$. Thus, N costs were \$0, \$268.24, $\$ 536.48, \$ 804.72$, and $\$ 1072.96$ for 0,56 , 112,168 , and $224 \mathrm{~kg} \cdot \mathrm{ha}^{-1} \mathrm{~N}$, respectively. Labor costs of $\$ 12$ per harvested $t$ were estimated assuming a laborer will harvest $100,10-\mathrm{kg}$ pumpkin fruit per hour, at a wage of $\$ 12$ per hour, which relates to $\approx \$ 0.012$ per $\mathrm{kg}$. This equates to one person harvesting enough pumpkins to fill three 30 - to 35 -count bins per hour. Labor costs are based on the weight of fruit obtained for each $\mathrm{N}$ fertilizer rate. The total costs were estimated as an additional $\$ 3725$ per ha, which is estimated from fixed and variable costs (without fertilizer and harvest labor costs) based on jack-olantern pumpkin production costs and revenue projections (Walters, 2005). The fertilizer and harvest labor costs were added later depending on $\mathrm{N}$ rate and resulting yields. The gross revenues were calculated from pumpkin weights obtained per hectare at the specific $\mathrm{N}$ rates evaluated and multiplied by $\$ 0.33, \$ 0.44$, or $\$ 0.55$ per $\mathrm{kg}$, reflecting a range of prices, depending on the market where pumpkins are sold. Net revenues were calculated based on gross revenues - total costs. Return on fertilizer investment (ROFI) was also calculated based on pumpkin net revenues generated at each price point, with ROFI calculated as

\section{[(Gain from Fertilizer Investment \\ - Cost of Fertilizer Investment) \\ / Cost of Fertilizer Investment] $\times 100$}

Data were subjected to analysis of variance using the general linear models procedure of SAS (version 9.2; SAS Institute, Cary, NC) appropriate for a split plot experimental design to determine the effects of pumpkin cultivar and $\mathrm{N}$ fertilizer rates on leaf chlorophyll content and fruit yield. No interactions $(P>0.05)$ were observed between pumpkin cultivar or $\mathrm{N}$ rate and year, thus data were pooled over years. Furthermore, no interactions $(P>0.05)$ were detected between main effect treatments of cultivar and $\mathrm{N}$ rate. Fisher's protected least significant difference (LSD) test was used to separate pumpkin cultivar differences at $P \leq 0.05$. Regression analyses were also used to ascer- tain the relationship between $\mathrm{N}$ rate and leaf chlorophyll content, fruit yield, production costs, gross and net revenues, and ROFI with best models determined based on higher adjusted and predicted $R^{2}$ values and low $P$ values. On the basis of Cerrato and Blackmer (1990), these data were fit to linear, linearplateau, quadratic, and quadratic-plateau, and cubic models using PROC REG and PROC NLIN in SAS. However, ROFI did not fit any of the models tested, so Fisher's protected LSD test was used to separate $\mathrm{N}$ rates for three ROFI price points at $P \leq 0.05$.

\section{Results}

The wheat crop residues remaining after harvest operations contributed significant organic mulch residue over the soil surface. For both growing seasons, wheat stubble and straw left from harvest operations were visually estimated to provide $\approx 75 \%$ to $80 \%$ soil coverage. The wheat stubble was $\approx 10 \mathrm{~cm}$ in height each year, and straw was evenly distributed over the soil surface. The amount of water received at any rainfall event during the growing season in each year was not sufficient to cause leaching or runoff of applied $\mathrm{N}$.

Pumpkin cultivar. Pumpkin cultivars did not differ $(P>0.05)$ for leaf chlorophyll content at either sampling date (Table 1). However, differences were observed among the cultivars for pumpkin fruit and yield parameters. 'Appalachian' produced the highest pumpkin yields at $48,800 \mathrm{~kg} \cdot \mathrm{ha}^{-1}$, although it did not differ from 'Gold Medal' at $43,700 \mathrm{~kg} \cdot \mathrm{ha}^{-1}$. 'Magic Wand' produced the lowest weights at $39,000 \mathrm{~kg} \cdot \mathrm{ha}^{-1}$ but did not differ $(P>0.05)$ from 'Gold Medal'. 'Appalachian' and 'Magic Wand' both produced 6900 fruit/ha, and 'Gold Medal' produced the fewest at 5400 fruit/ha. All cultivars differed $(P \leq 0.05)$ for average fruit weight and diameter. 'Gold Medal' produced the largest fruits, averaging $8.1 \mathrm{~kg}$, followed by 'Appalachian' at $7.1 \mathrm{~kg}$ and 'Magic
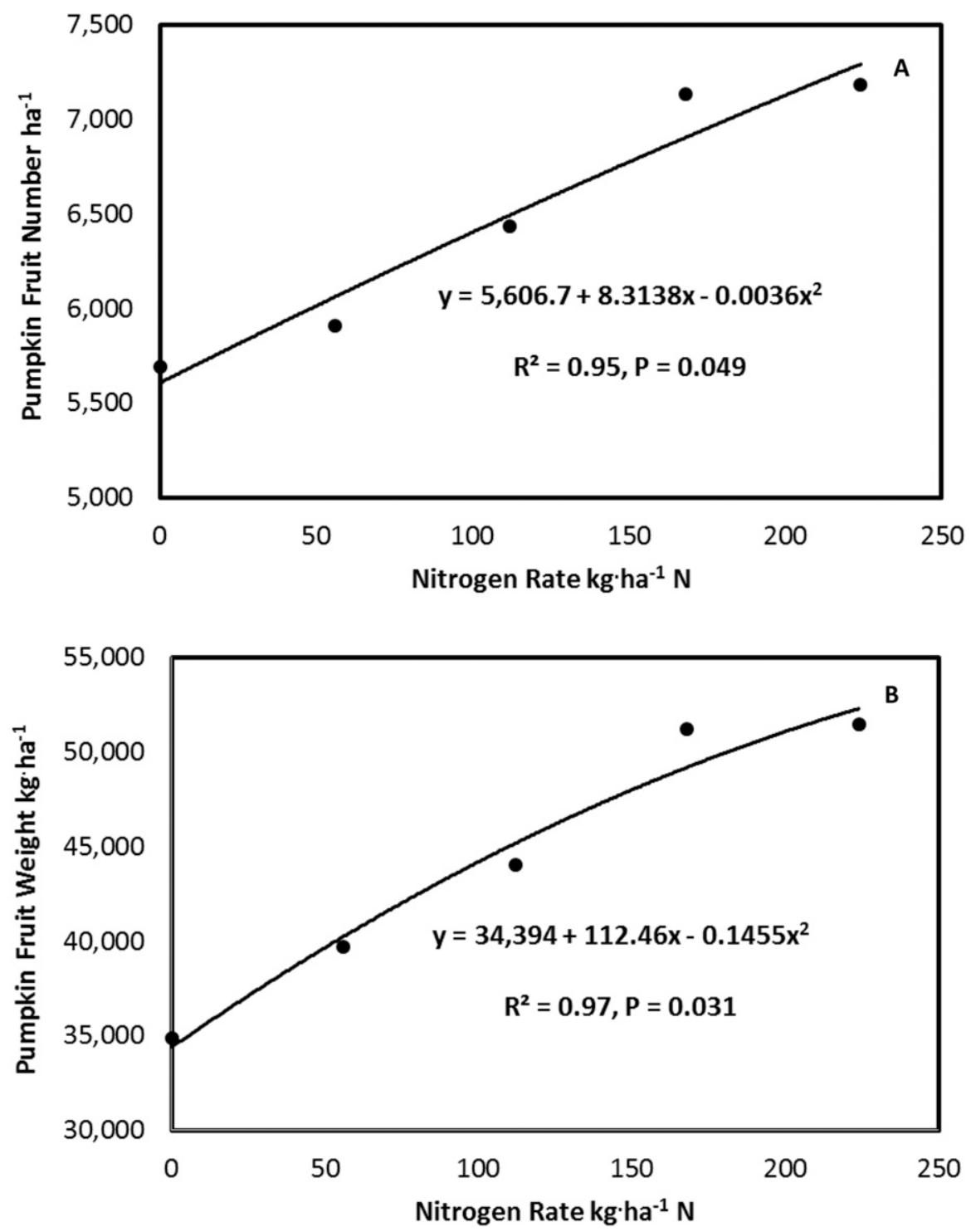

Fig. 2. Relationship of nitrogen $(\mathrm{N})$ fertilizer rate in no-tillage pumpkin production system with (A) pumpkin fruit number/ha, and (B) pumpkin fruit weight $\left(\mathrm{kg} \cdot \mathrm{ha}^{-1}\right)$. 
Wand' at $5.7 \mathrm{~kg}$. 'Gold Medal' had the largest fruit diameter at $28.2 \mathrm{~cm}$, with 'Magic Wand' and 'Appalachian' producing smaller fruit with diameters of 25.7 and $23.2 \mathrm{~cm}$, respectively. 'Appalachian' fruit tend to be more elongated and had the smallest diameter of all cultivars evaluated.

$N$ application rate. Nitrogen application rate affected pumpkin leaf chlorophyll content. Leaf chlorophyll content in pumpkin for both sampling dates was best described by quadratic models (Fig. 1). As the $\mathrm{N}$ application rate increased, leaf chlorophyll content also increased in the plant. For the midseason sampling (10 Aug.), the chlorophyll content value was 35.9 for the treatment with no fertilizer and increased in a quadratic manner to 44.9 at the $224 \mathrm{~kg} \cdot \mathrm{ha}^{-1} \mathrm{~N}$ application rate. At the late-season sampling (10 Sept.), the leaf chlorophyll content value was 26.8 for the no $\mathrm{N}$ fertilizer treatment, with a quadratic relationship best describing the increase to 42.8 at the $224 \mathrm{~kg} \cdot \mathrm{ha}^{-1} \mathrm{~N}$ application rate. However, the slope coefficient of the quadratic model was larger for the late-season sampling date compared with early season, indicating a greater effect of each $\mathrm{N}$ rate at this later timing.

Pumpkin fruit number and yield in the NT system were influenced by $\mathrm{N}$ application rate. The relationship of total pumpkin fruit number and weight per hectare were best described by quadratic models (Fig. 2A and B) with 168 and $224 \mathrm{~kg} \cdot \mathrm{ha}^{-1} \mathrm{~N}$ providing the greatest yield increases compared with no N. Pumpkin fruit number and weight per hectare increased by $\approx 23 \%$ and $48 \%$, respectively, as application rates increased from 0 to 224 $\mathrm{kg} \cdot \mathrm{ha}^{-1} \mathrm{~N}$. Applications of 168 and 224 $\mathrm{kg} \cdot \mathrm{ha}^{-1} \mathrm{~N}$ produced the greatest pumpkin yields, as these rates resulted in high fruit number and weight per hectare, compared with the lower $\mathrm{N}$ fertilizer rates. With applications of 168 and $224 \mathrm{~kg} \cdot \mathrm{ha}^{-1} \mathrm{~N}$, pumpkin fruit number was slightly more than 7000 fruit/ha, and pumpkin weight was slightly more than $51,000 \mathrm{~kg} \cdot \mathrm{ha}^{-1}$.

Nitrogen application rate affected average pumpkin fruit weight and diameter, with quadratic models best explaining these relationships (Fig. 3A and B). Average fruit weight increased by $20 \%$ and diameter rose by $18 \%$ as application rates increased from 0 to $224 \mathrm{~kg} \cdot \mathrm{ha}^{-1} \mathrm{~N}$. Nitrogen rates of 168 and $224 \mathrm{~kg} \cdot \mathrm{ha}^{-1} \mathrm{~N}$ resulted in pumpkins having similar average fruit weight and diameter, with both of these rates producing larger fruit than pumpkin plants fertilized with lower $\mathrm{N}$ rates.

Higher amounts of $\mathrm{N}$ applied per hectare led to an increase in associated labor and total input costs but also substantially improved gross and net revenues at three pumpkin price points. Linear relationships best described the influence of $\mathrm{N}$ fertilizer rate on resulting labor and total input costs (Fig. 4). These costs were higher but similar for the 168 and $224 \mathrm{~kg} \cdot \mathrm{ha}^{-1} \mathrm{~N}$ rates compared with the 0,56 , and $112 \mathrm{~kg} \cdot \mathrm{ha}^{-1} \mathrm{~N}$ rates. The increase in gross and net revenues with $\mathrm{N}$ fertilizer rate were best described by quadratic models up to 224
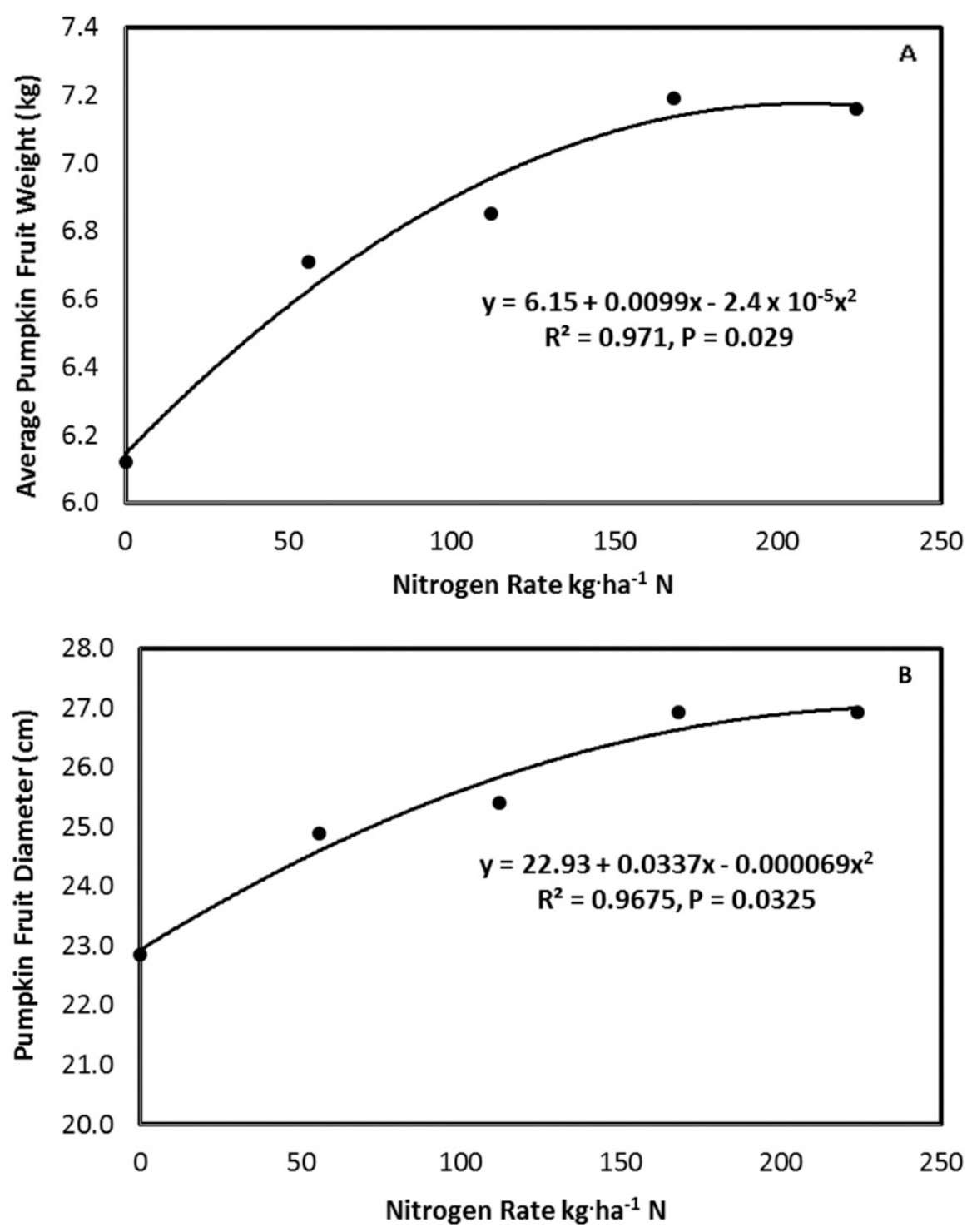

Fig. 3. Impact of nitrogen $(\mathrm{N})$ fertilizer rate on $(\mathbf{A})$ average pumpkin fruit size (kilograms) and $(\mathbf{B})$ pumpkin fruit diameter (centimeters) in a no-tillage production system.

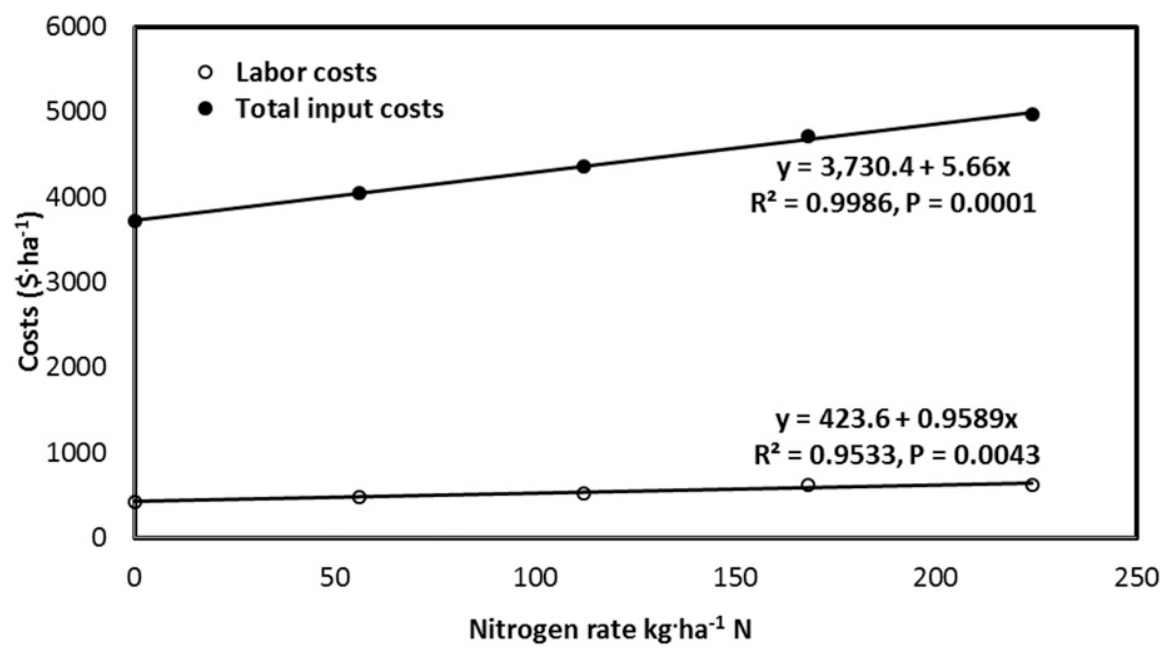

Fig. 4. Influence of nitrogen $(\mathrm{N})$ fertilizer rate on associated labor and total input costs for no-tillage pumpkin production. 
$\mathrm{kg} \cdot \mathrm{ha}^{-1} \mathrm{~N}$ at each of three common price selling points (Fig. 5A and B). Net revenues for NT pumpkins were $\$ 7778, \$ 11,613$, and $\$ 15,447$ per ha at $\$ 0.33, \$ 0.44$, or $\$ 0.55$ per $\mathrm{kg}$, respectively, when no $\mathrm{N}$ was applied. Net revenues increased to $\$ 12,001, \$ 17,657$, and $\$ 23,319$ for those same pricing points, respectively, when $224 \mathrm{~kg} \cdot \mathrm{ha}^{-1} \mathrm{~N}$ was applied (Fig. 5B). This study indicated that an application of $224 \mathrm{~kg} \cdot \mathrm{ha}^{-1} \mathrm{~N}$ in NT pumpkin production would increase net revenues by $\approx 54 \%, 52 \%$, and $51 \%$ at the price points of $\$ 0.33, \$ 0.44$, and $\$ 0.55$ per $\mathrm{kg}$, respectively, compared with no $\mathrm{N}$ fertilizer applications.

The cost of $\mathrm{N}$ fertilizer applications in NT pumpkin production is an important investment considering the increased revenues that are generated when optimal $\mathrm{N}$ rates are used. The estimated $\mathrm{N}$ application costs were $\approx \$ 4.79 / \mathrm{kg} \mathrm{N}$. The $168 \mathrm{~kg} \cdot \mathrm{ha}^{-1} \mathrm{~N}$ provided the highest ROFI for all price points, and a grower would get a return of $\approx 449 \%, 672 \%$, and $896 \%$ on that investment (additional monetary gain from 0 to $168 \mathrm{~kg} \cdot \mathrm{ha}^{-1} \mathrm{~N}$ ) when pumpkins are sold at $\$ 0.33, \$ 0.44$, and $\$ 0.55$ per kg, respectively (Table 2). The highest $\mathrm{N}$ rate $\left(224 \mathrm{~kg} \cdot \mathrm{ha}^{-1}\right)$ provided the least return on fertilizer investment for all price points, with both the 56 and $112 \mathrm{~kg} \cdot \mathrm{ha}^{-1} \mathrm{~N}$ rates resulting in a higher ROFI. This indicates that $\mathrm{N}$ fertilizer applications are a valuable investment in NT pumpkin production to improve net revenues.

\section{Discussion}

Appropriate $\mathrm{N}$ fertilizer investments will provide significant yield improvements and increased monetary returns in NT pumpkin production systems (Figs. 2, 5A and B). Our study indicated that NT pumpkin yields and revenues could be significantly improved at optimal $\mathrm{N}$ application rates. Quadratic models best explained the increase in pumpkin yields and revenues as $\mathrm{N}$ application rates increased from 0 to $224 \mathrm{~kg} \cdot \mathrm{ha}^{-1}$. Harrelson et al. (2008) indicated that the highest $\mathrm{N}$ rate applied to NT pumpkins in their study (120 $\mathrm{kg} \cdot \mathrm{ha}^{-1} \mathrm{~N}$ ) provided the greatest yield and that higher pumpkin yields would likely be possible at even greater $\mathrm{N}$ rates.

The recommended $\mathrm{N}$ rate for pumpkins produced in the Midwest for CT soils with less than $3 \%$ organic matter is $101 \mathrm{~kg} \cdot \mathrm{ha}^{-1}$ (Egel et al., 2017), with a preplant broadcast application of $56 \mathrm{~kg} \cdot \mathrm{ha}^{-1}$ and a sidedress application of $45 \mathrm{~kg} \cdot \mathrm{ha}^{-1}$ at the onset of vining. Our study indicated that compared with $\mathrm{CT}$, an additional $123 \mathrm{~kg} \cdot \mathrm{ha}^{-1} \mathrm{~N}$ is required to maximize NT pumpkin net revenues planted after wheat harvest when there are significant amounts of small grain straw residues on the soil surface. Additionally, pumpkins grown in NT systems using a winter grain crop that is ended at flowering should require similar $\mathrm{N}$ amounts because $\mathrm{N}$ is mostly used in wheat during vegetative growth with little $\mathrm{N}$ used during heading and grain ripening (Malhi et al., 2006).

Nitrogen sources play an important role in availability to pumpkin plants. The predom-
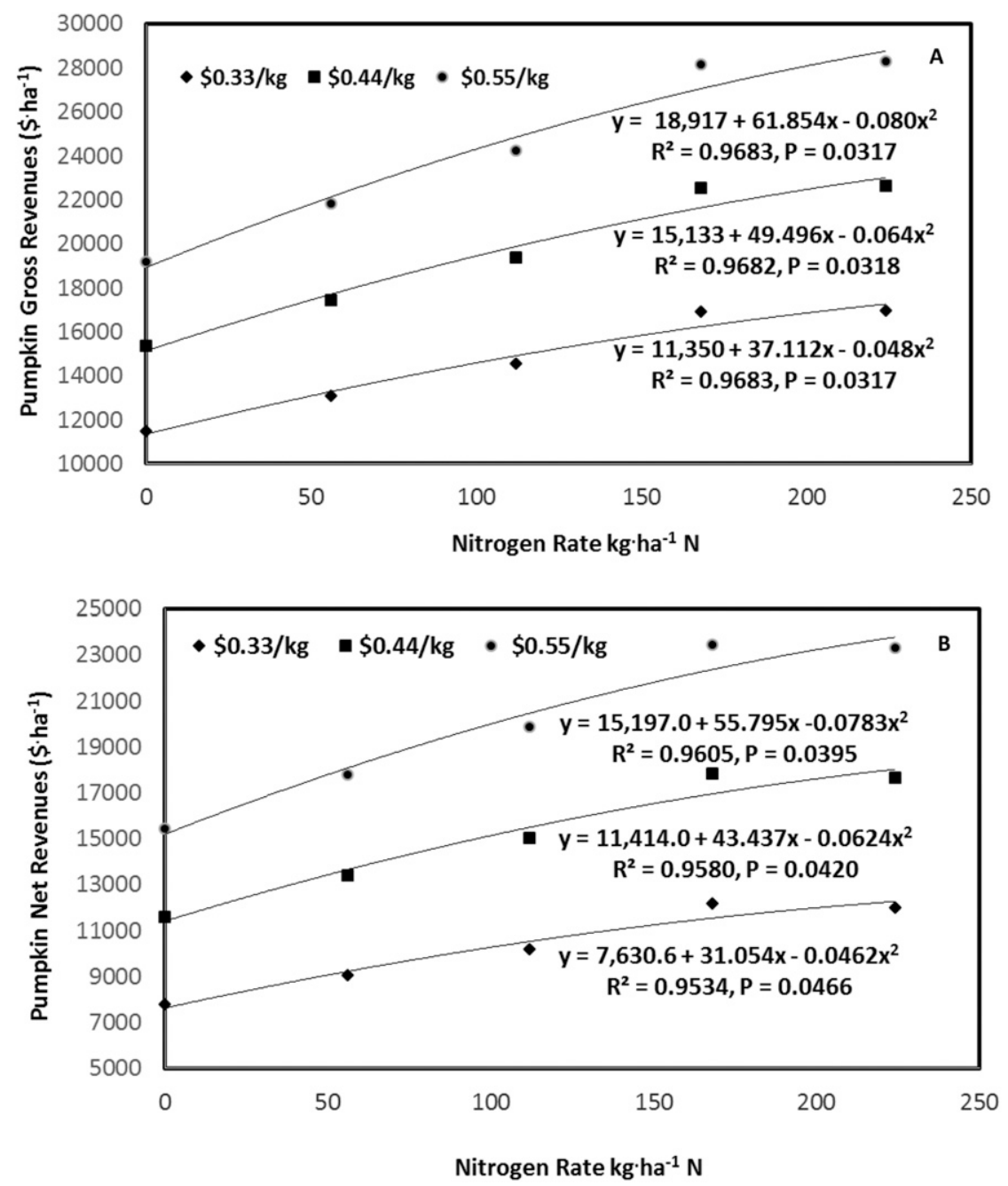

Fig. 5. Influence of nitrogen $(\mathrm{N})$ fertilizer rate on no-tillage pumpkin $(\mathbf{A})$ gross and $(\mathbf{B})$ net revenues $(\$ /$ ha) at several common pricing points.

inant form of $\mathrm{N}$ used in this study was nitrate, which is readily leachable. Due to the two application timings used (10 July and 10 Aug.), and that supplemental irrigation was required each week in both growing seasons to provide sufficient water, leaching of nitrate should not have been an issue to influence the results obtained. Additionally, the organic $\mathrm{N}$ measured in soil before pumpkin seedling transplanting $\left(62 \mathrm{~kg} \cdot \mathrm{ha}^{-1}\right)$ was not considered as part of the amount of recommended $\mathrm{N}$ because release of $\mathrm{N}$ from organic matter in the soil is inconsistent over a 3- to 4-month growing season. The release of $\mathrm{N}$ from organic matter is difficult to estimate because it is controlled by the soil environment, especially available moisture, temperature, and microbial populations (Agehara and Warnke, 2005 ). However, $\approx 1 \%$ organic matter in soil will typically release on average $\approx 10 \mathrm{~kg} \cdot \mathrm{ha}^{-1} \mathrm{~N}$ over the course of a growing season (Walters, 2016). On NT pumpkin sites having significantly more soil organic matter than that found in our study, optimal $\mathrm{N}$ rates may be lower than what is reported herein due to more $\mathrm{N}$ released over the course of a growing season.

Other macronutrients, such as $\mathrm{P}$ and $\mathrm{K}$, should not have influenced the outcomes of
Table 2. Return on fertilizer investment (ROFI) based on pumpkin net revenues generated at each price point.

\begin{tabular}{lccc}
\hline $\begin{array}{l}\text { N rate } \\
\left(\mathrm{kg} \cdot \mathrm{ha}^{-1}\right)\end{array}$ & \multicolumn{3}{c}{ ROFI at three price points } \\
\cline { 2 - 4 }$\$ 0.33 / \mathrm{kg}$ & $\$ 0.44 / \mathrm{kg}$ & $\$ 0.55 / \mathrm{kg}$ \\
\hline 0 & $0 \mathrm{D}^{\mathrm{y}}$ & $0 \mathrm{D}$ & $0 \mathrm{D}$ \\
56 & $373 \mathrm{~B}$ & $571 \mathrm{~B}$ & $768 \mathrm{~B}$ \\
112 & $347 \mathrm{~B}$ & $535 \mathrm{~B}$ & $724 \mathrm{~B}$ \\
168 & $449 \mathrm{~A}$ & $672 \mathrm{~A}$ & $896 \mathrm{~A}$ \\
224 & $294 \mathrm{C}$ & $463 \mathrm{C}$ & $634 \mathrm{C}$ \\
\hline
\end{tabular}

${ }^{\mathrm{z}}$ ROFI calculated as [(Gain from Fertilizer Investment - Cost of Fertilizer Investment) / Cost of Fertilizer Investment] $\times 100$.

${ }^{\mathrm{y}}$ Means separated by the same letter within a column are not significantly different according to Fisher's protected least significant difference at $P \leq 0.05$

this study because fields were maintained with significant applications of diammonium phosphate and potassium chloride each year, and the soil $\mathrm{pH}$ was in acceptable range for efficient uptake. There were no visible symptoms of $\mathrm{P}$ or $\mathrm{K}$ deficiencies observed on pumpkin plants at any time during the growing season. The deficiencies of $\mathrm{P}$ and $\mathrm{K}$ can both have a direct influence on resulting pumpkin yields and fruit quality; thus, these 
macronutrients had to be maintained at proper levels because results obtained would have reflected more on the lack of these nutrients than on $\mathrm{N}$ fertilizer rates.

This study indicated that proper management of $\mathrm{N}$ fertility is crucial to maximize yield and fruit size in NT pumpkin production. $\mathrm{N}$ fertilizer investments were shown to provide significant monetary returns in NT pumpkin production systems. Although growers often look for ways to reduce input costs in vegetable production systems, $\mathrm{N}$ fertilization is clearly an important investment that provides increased yields and revenues in NT pumpkins.

\section{Literature Cited}

Agehara, S. and D.D. Warnke. 2005. Soil moisture and temperature effects on nitrogen release from organic nitrogen sources. Soil Sci. Soc. Amer. J. 69:1844-1855.

Bray, R.H. and L.T. Kurtz. 1945. Determination of total, organic, and available forms of phosphorus in soils. Soil Sci. 59:39-46.

Cerrato, M.E. and A.M. Blackmer. 1990. Comparison of models for describing corn yield response to nitrogen fertilizer. Agron. J. 82:138-143.

Egel, D., R. Foster, E. Maynard, R. Weinzierl, M. Babadoost, H. Tabor, R. Bauernfeind, T. Carey, M. Kennelly, B. Hutchison, and S. Gu. 2010. Midwest vegetable production guide for commercial growers 2010. Univ. of Illinois Ext. Bul. C1373-10, Champaign-Urbana, IL.

Egel, D., R. Foster, E. Maynard, S. Weller, M. Babadoost, A. Nair, C. Rivard, M. Kennelly, M. Hausbeck, Z. Szendra, B. Hutchison, A. Orshinsky, T. Eaton, C. Welty, and S. Miller. 2017. Midwest vegetable production guide for commercial growers 2017. Univ. of Illinois Ext. Bul. C1373-17, Champaign-Urbana, IL.
Francis, G.S., K.M. Bartley, and F.J. Tabley. 1998. The effect of winter cover crop management on nitrate leaching losses and crop growth. J. Agric. Sci. 131:299-308.

Harrelson, E.R., G.D. Hoyt, J.L. Havlin, and D.W Monks. 2007. Effect of winter cover crop residue on no-till pumpkin yield. HortScience 42:1568-1574.

Harrelson, E.R., G.D. Hoyt, J.L. Havlin, and D.W. Monks. 2008. Effect of planting date and nitrogen fertilization rates on no-till pumpkins. HortScience 43:857-861.

Herman, R.J. 1979. Soil Survey of Jackson County, Illinois. Illinois Agr. Expt. Sta. Soil Rpt. 106.

Hoyt, G.D., D.W. Monks, and T.J. Monaco. 1994. Conservation tillage for vegetable production. HortTechnology 4:129-135.

Johnson, A.M. and G.D. Hoyt. 1999. Changes to the soil environment under conservation tillage. HortTechnology 9:380-393.

Kjeldahl, J. 1883. Neue Methode zur Bestimmung des Stickstoffs in organischen Korpern. Z. Anal. Chem. 22:366-382.

Knavel, D.E. and J.W. Herron. 1986. Response of vegetable crops to nitrogen rates in tillage systems with and without vetch and ryegrass. J. Amer. Soc. Hort. Sci. 111:502-507.

Malhi, S.S., A.M. Johnston, J.J. Schoenau, Z.H. Wang, and C.L. Vera. 2006. Seasonal biomass accumulation and nutrient uptake of wheat, barley and oat on a Black Chernozem soil in Saskatchewan. Can. J. Plant Sci. 86:10051014.

Mehlich, A. 1984. Mehlich 3 soil test extractant: A modification of the Mehlich 2 extractant. Commun. Soil Sci. Plant Anal. 15:1409-1416.

Morse, R.D. and D.L. Seward. 1986. No-tillage production of broccoli and cabbage. Appl. Agric. Res. 1(2):96-99.

Morse, R., T. Elkner, and S. Groff. 2001. No-till pumpkin production principles and practices. Pennsylvania Marketing and Research Program, Harrisburg, PA. 16 p.
O'Rourke, M.E. and J. Peterson. 2016. Reduced tillage impacts on pumpkin yield, weed pressure, soil moisture and soil erosion. HortScience 51:1524-1528.

Paul, E.A. and F.E. Clark. 1996. Soil Microbiology and Biochemistry. 2nd ed. Academic Press Inc., London, UK.

Rapp, H.S., R.R. Bellinder, H.C. Wien, and F.M. Vermeylen. 2004. Reduced tillage, rye residues, and herbicides influence weed suppression and yield of pumpkins. Weed Technol. 18:953-961.

Sanders, D.C. 2006. Southeastern U.S. 2006 Vegetable Crop Handbook. Vance Publishing Corporation, Lincolnshire, IL.

Schonbeck, M., S. Herbert, R. DeGregorio, F. Mangan, K. Guillard, E. Sideman, J. Herbst, and R. Jaye. 1993. Cover cropping system in the northeastern United States: I. Cover crop and vegetable yields, nutrients, and soil conditions. J. Sustain. Agr. 3:105-132.

Skarphol, B.J., K.A. Corey, and J.J. Meisinger. 1987. Response of snap beans to tillage and cover crop combinations. J. Amer. Soc. Hort. Sci. 112:936-941.

Vyn, T.J., K.L. Janovicek, M.H. Miller, and E.G. Beauchamp. 1999. Soil nitrate accumulation and corn response to preceding small-grain fertilization and cover crops. Agron. J. 91:1724.

Walters, S.A. 2016. No-Tillage Production Systems for Cucurbit Vegetables, p. 129-138. In: M. Pessaraki (ed.). Handbook of Cucurbits, CRC Press, Boca Raton, FL.

Walters, S.A. 2005. Jack-o-lantern pumpkin production costs and revenue projections. Southern Illinois University-Carbondale, College of Agricultural Sciences, SIUC Horticultural Factsheet 1 .

Walters, S.A., B.G. Young, and R.F. Krausz. 2008. Influence of tillage, cover crop, and preemergence herbicides on weed control and pumpkin yield. Intl. J. Veg. Sci. 14(2):148-161. 